\title{
FIRST RECORD OF THE MOSASAUR PLATECARPUS COPE, 1869 FROM SOUTH AMERICA AND ITS SYSTEMATIC IMPLICATIONS
}

\author{
PETER BENGTSON \\ Geologisch-Paläontologisches Institut, Im Neuenheimer Feld 234, DE-69120 Heidelberg, Germany. bengtson@uni-hd.de \\ JOHAN LINDGREN \\ Geological Museum, University of Copenhagen, Øster Voldgade 5-7, DK-1350 København K, Denmark. Dept. of Geology, \\ GeoBiosphere Science Centre, Lund University, Sölvegatan 12, SE-22362 Lund, Sweden. johan.lindgren@geol.lu.se
}

\begin{abstract}
Two isolated, presumably shed, marginal tooth-crowns of the mosasaur Platecarpus sp. are described from the upper Turonian and Turonian-Coniacian (Upper Cretaceous) of the Sergipe Basin in northeastern Brazil. They represent the first record of the genus from South America, thus extending the geographic range of Platecarpus beyond Africa, Europe and North America. It is suggested that Platecarpus originated in the northern part of the incipient South Atlantic Ocean during the early Late Cretaceous.
\end{abstract}

Keywords: Platecarpus, Mosasauridae, Turonian, Coniacian, Cretaceous, Sergipe, Brazil.

\begin{abstract}
RESUMO - São descritas duas coroas dentais marginais, provavelmente descartadas, do mosassauro Platecarpus sp., provenientes do Turoniano superior e Turoniano-Coniaciano da bacia de Sergipe, Nordeste do Brasil. Representam o primeiro registro deste gênero da América do Sul, e estendendo, assim, a sua distribuição geográfica para além da África, Europa e América do Norte. Sugere-se que o gênero Platecarpus tenha se originado no iníco do Neo-Cretáceo na região setentrional do incipiente Oceano Atlântico Sul.
\end{abstract}

Palavras-chave: Platecarpus, Mosasauridae, Turoniano, Coniaciano, Cretáceo, Sergipe, Brasil.

\section{INTRODUCTION}

The marine Cretaceous rocks exposed in the Sergipe Basin in northeastern Brazil (Figure 1) contain a rich macroinvertebrate fauna dominated by ammonites (Bengtson, 1996, 1999, and references therein), bivalves (e.g., Bengtson, 1983; Hessel, 1988; Seeling \& Bengtson, 1999; 2003a, 2003b; Andrade et al., 2003, 2004), gastropods (Burrer et al., 2002) and echinoids (e.g., Smith \& Bengtson, 1991; Manso \& Souza-Lima, 2003). Vertebrate remains are locally common and mainly represented by scales, teeth, and vertebrae of bony fishes, whereas reptilian remains are rare (Bengtson, 1983). Here we describe two isolated, presumably shed, marginal tooth-crowns of the mosasaur Platecarpus Cope, 1869, from the upper Turonian and near TuronianConiacian, respectively. For biostratigraphic data and locality descriptions, see Bengtson (1983, appendix 1) and Koutsoukos \& Bengtson (1993).

The Mosasauridae is geographically one of the most widely distributed groups of Cretaceous marine tetrapods, with reported occurrences from all continents, including Antarctica (e.g., Gasparini \& del Valle, 1981, 1984; Martin et al., 1999; Novas et al., 2002). Among the mosasaurs, Platecarpus is one of the most widespread genera; it has been reliably identified from Africa, Europe and North America, (e.g., Thévenin, 1896; Antunes, 1964; Russell, 1967; Bardet et al., 1991), and now also from South America. Reports from New Zealand (Lingham-Soliar, 1994) are probably based on a misidentification (Bell et al., 1999). The vast majority of reports of Platecarpus are from the Santonianlower Campanian of the Western Interior of North America (Russell, 1988). Older North American occurrences include, 
for example, the upper Coniacian of the Smoky Hill Chalk in Kansas (Everhart, 2003) and the Coniacian of the Austin Chalk in Texas (Thurmond, 1969).

In general, mosasaur remains from the Turonian are rare and fragmentary. Platecarpus is one of the few genera with a reliable Turonian record, as demonstrated by a reasonably complete skull of $P$. bocagei (Antunes, 1964) collected from the Kwanza (Cuanza) basin in Angola (Antunes, 1964; Lingham-Soliar, 1994). The presence of Platecarpus in Brazil widens the paleobiogeographic range of the genus beyond Africa, Europe and North America, and the Turonian age supports its inferred basal position within the evolution of the Mosasauridae.

\section{GEOLOGICAL SETTING}

The Sergipe Basin is located in the coastal and contiguous offshore part of the state of Sergipe in northeastern Brazil (Figure 1). It is one of the numerous South Atlantic continental margin basins that were formed as a result of rifting and separation of South America from Africa in late Mesozoic times. Structurally, the basin forms a half-graben, which is limited to the south-east by the continental slope and to the north-west by a system of normal faults. The sedimentary fill comprises a basal, Upper Carboniferous to middle Aptian non-marine succession and an Aptian to Miocene marine succession, which together represent one of the most complete Cretaceous sequences recorded in the South Atlantic marginal basins (Souza-Lima et al., 2002, and references therein).

The marine succession consists of the carbonate Riachuelo and Cotinguiba formations and the clastic Calumbi Formation (Figure 1C). The material described herein derives from the Cotinguiba Formation, which was deposited during the Cenomanian-Coniacian interval in neritic to upper bathyal environments under moderately dysoxic to fully anoxic bottom conditions and well-oxygenated epipelagic conditions (Bengtson, 1983; Berthou \& Bengtson, 1988; Koutsoukos et al., 1991). The formation is dated primarily with ammonites, inoceramid bivalves and foraminifers (Bengtson, 1983; Kauffman \& Bengtson, 1985; Koutsoukos \& Bengtson, 1993; Seeling \& Bengtson 2003a; Andrade et al., 2003, and unpublished results). The age of the two mosasaur teeth described here is established as late Turonian and Turonian-Coniacian, respectively, on the basis of ammonites and inoceramids.

The geological evolution and the development of the marine Cretaceous of the Sergipe Basin have been discussed at length by several authors, e.g., Ojeda \& Fugita (1976), Ojeda (1982), Bengtson (1983), Koutsoukos \& Bengtson (1993), Koutsoukos et al. (1993), Feijó (1995) and Souza-Lima et al. (2002). For more detailed information on the evolution of the Cretaceous carbonate succession the reader is referred to Koutsoukos et al. (1993).

\section{PREVIOUS WORK}

Occurrences of early mosasauroids (apart from aigialosaurs) are based mainly on isolated remains (e.g., Lundelius \& Warne, 1960; Martin \& Stewart, 1977; Bell \& VonLoh, 1998; Vilas Bôas \& Carvalho 2001), although reasonably complete skeletons have been collected from the upper(?) Turonian of Angola (Antunes, 1964; Lingham-Soliar, 1994), the upper Turonian of Colombia (Páramo-Fonseca, 2000) and the lower Turonian of Morocco (Bardet et al., 2003). A nearly complete skeleton (No. PMU R163, Museum of Evolution, Uppsala University, Sweden) of the basal mosasaur Halisaurus sternbergi (Wiman, 1920) from the upper Coniacian-lowermost Campanian Smoky Hill Chalk Member of the Niobrara Formation in western Kansas, USA, provides a rare insight into the anatomy of early members of the mosasaur group (Bardet \& Pereda Suberbiola, 2001). In this species, the most fundamental adaptations to a life in the marine realm, such as dorsally located nares and a laterally compressed tail, had already evolved, although a number of characters, including the primitive configuration and morphology of the limb elements, indicate a terrestrial origin (see, e.g., Bardet \& Pereda Suberbiola, 2001, fig. 1).

Mosasaur teeth have long been known from Brazil, with records of the genera Globidens Gilmore, 1912 and Mosasaurus Conybeare, 1822 from the upper Campanian-Maastrichtian of the Pernambuco-Paraíba Basin (Price, 1953, 1957; Carvalho, 1996; Carvalho \& Azevedo, 1998) and Plioplatecarpus Dollo, 1882 (including vertebrae) from the upper Campanian of the Sergipe Basin (Souza-Lima, 2001; Bertini, 2002). Indeterminate mosasaurine teeth from the São Luís Basin (Maranhão) were described and dated as Cenomanian on palynological grounds (Eugênio, 1994; Vilas Bôas \& Carvalho, 2001), although a later age cannot be excluded (I.S. Carvalho, UFRJ, Rio de Janeiro, in litt., 9 February 2004). Records from the Acre Basin in westernmost Brazil are considered doubtful (Brito et al., 1992).

The genus Platecarpus has previously not been definitely identified from Brazil. Carvalho \& Azevedo (1998) reported isolated teeth from the Pernambuco-Paraíba Basin showing features characteristic of this genus but assigned them only broadly to the subfamily Plioplatecarpinae Their brief description and sketchy drawings do not allow a generic determination.

\section{SYSTEMATIC PALAEONTOLOGY}

Dental terminology used herein follows mainly that of Lindgren \& Siverson (2002, fig. 2). Institutional abbreviations: MN, Museu Nacional, Rio de Janeiro, Brazil; PMU, Museum of Evolution, Palaeontology Section, Uppsala University, Uppsala, Sweden; FHSM, Sternberg Museum of Natural History, Fort Hays State University, Hays, Kansas, USA. 

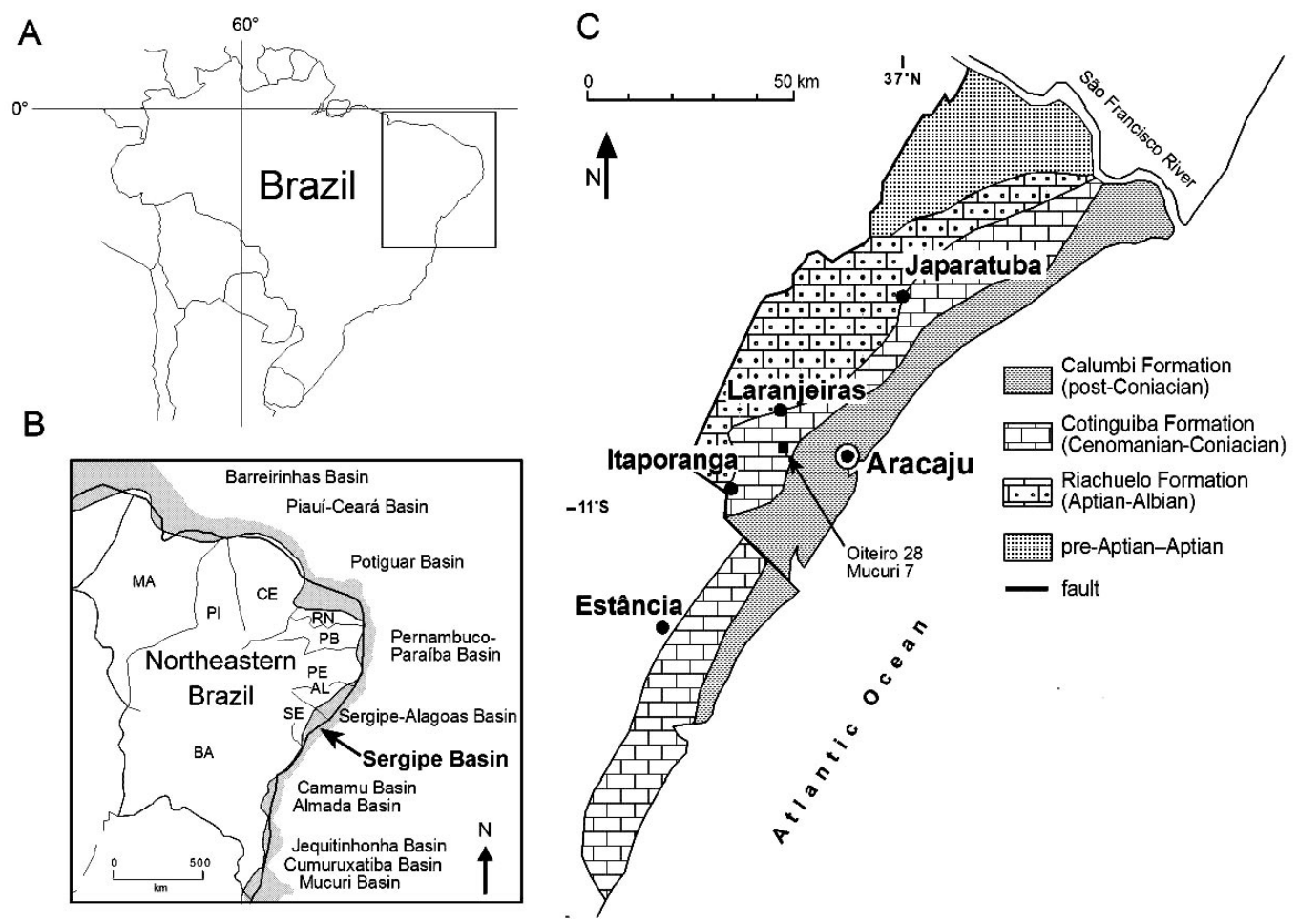

Figure 1. A- B,. Location of the Sergipe Basin and other continental margin basins in northeastern Brazil. C. Geology of onshore portion of the Sergipe Basin below the non-marine Cenozoic cover, with mosasaur localities Oiteiro 28 and Mucuri 7 (adapted from Bengtson, 1983 and Seeling \& Bengtson, 2003). Abbreviations: AL, Alagoas; BA, Bahia; CE, Ceará; MA, Maranhão; PB, Paraíba; PE, Pernambuco; PI, Piauí; RN,

Order SQUAMATA Oppel, 1811

Family MOSASAURIDAE Gervais, 1853 Subfamily PLIOPLATECARPINAE Williston, 1897

Diagnosis. See Russell (1967).

Remarks. As defined by Lindgren (2004), isolated teeth of plioplatecarpine mosasaurs are readily distinguished from those of mosasaurines, tylosaurines and Halisaurus Marsh, 1869 on the basis of the following character state combination: (1) fine hairline striations on, at least, the basal portion of the lingual face of the crowns; (2) labial and lingual surfaces faceted, rendering the crowns a more or less prismatic appearance; (3) carinae prominent but lacking serrations; (4) crowns more or less abruptly curved distally from approximately the mid-point of their height; (5) basal cross-section elliptical to sub-circular; (6) labial and lingual surfaces on latero-posterior teeth almost equally convex, whereas anterior teeth have a gently convex labial face and a deeply U-shaped lingual surface; (7) crowns generally slender and slightly pointed in lateral view.

\section{Genus PLATECARPUS Cope, 1869}

Type species. Platecarpus tympaniticus Cope, 1869, from the Santonian Tombigbee Sand near Columbus, Mississippi.
Diagnosis. See Russell (1967).

Remarks. Despite being one of the best known mosasaur genera, the taxonomic status of Platecarpus is still unclear. In a recent phylogenetic revision of the Mosasauroidea, Bell (1997) concluded that Platecarpus is a paraphyletic genus and hence not a valid taxon. Moreover, the well-known $P$. ictericus (Cope, 1871) and P. coryphaeus (Cope, 1872) may both be junior synonyms of $P$. tympaniticus, as the characters previously used to distinguish between these three nominal species (e.g. Russell, 1967) most likely represent natural and/or ontogenic variation (Kiernan, 2002; Everhart, 2003, and references therein). Besides $P$. tympaniticus, three nominal species of Platecarpus are currently considered valid, i.e. P. planifrons (Cope, 1874) from the upper Coniacian-lower Santonian part of the Smoky Hill Chalk in Kansas, USA, P. bocagei (Antunes, 1964) from the upper (?) Turonian of Angola, and P. somenensis Thévenin, 1896 from the lower Campanian of France (e.g., Lingham-Soliar, 1994; Lindgren, 2004; but see also Everhart, 2003). In addition, Arambourg (1952) tentatively assigned his new species ptychodon from the Maastrichtian of Morocco to Platecarpus. Isolated teeth of 'P.' ptychodon share a few characters with Platecarpus, such as faceted labial and lingual surfaces. However, the low and compressed form of the crowns (see Arambourg, 1952, pl. 39, figs. 1-7) is markedly different from that seen in marginal teeth of $P$. 
tympaniticus, $P$. planifrons, $P$. somenensis and $P$. bocagei. 'Platecarpus' ptychodon is here considered as a valid species although of uncertain generic affinity. This view is supported by a recent find of a nearly complete skull in the Maastrichtian phosphates of Morocco, which is currently being examined at the Muséum National d'Histoire Naturelle in Paris, France (Bardet et al., 2004).

With the exception of $P$. somenensis and related forms (see Thévenin, 1896, pl. 30, figs. 1-2; Lindgren, 2004, figs. 2 , 4), the species of Platecarpus are equipped with fairly slender and pointed marginal teeth (see e.g., Cope, 1875, pl. 14, fig.

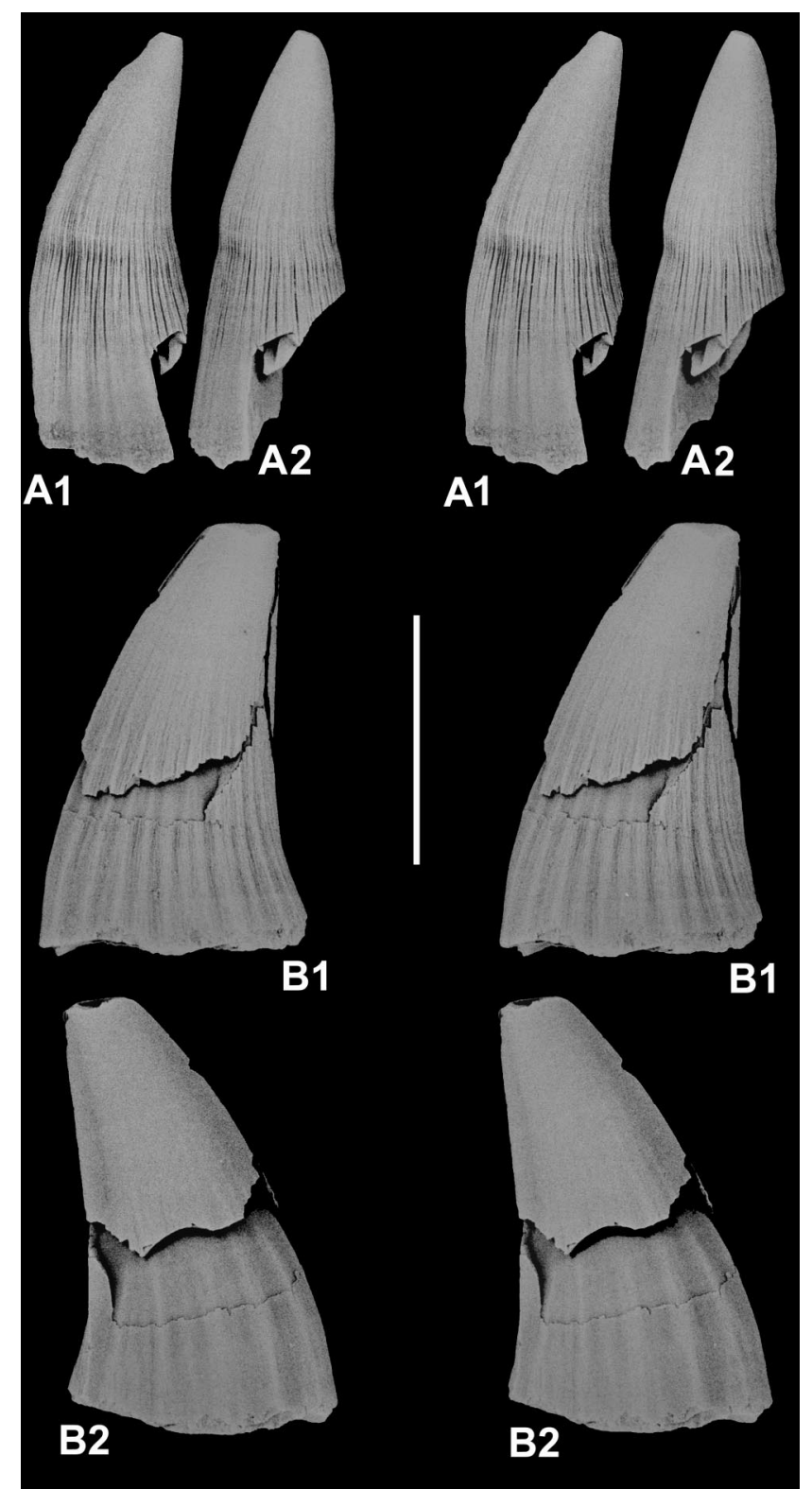

Figure 2. Stereopairs of marginal tooth-crowns of Platecarpus sp. from the Sergipe Basin, northeastern Brazil. A, MN 6940-V, from Oiteiro 28 (upper Turonian) in lingual (A1) and posterior (A2) views; B, MN 6941-V, from Mucuri 7 (Turonian-Coniacian), in lingual (B1) and labial (B2) views. Scale bar: $10 \mathrm{~mm}$.
3 ), probably as an adaptation for piscivorous feeding (Russell, 1967). In accordance with extant members of the Gavialidae (see Massare, 1987, fig. 1b), these mosasaurs probably captured their prey by piercing it with rows of weakly differentiated teeth that were specialized for penetrating between thin but closely spaced ribs.

The dental morphology of Platecarpus is closer to that of Plioplatecarpus than to any other plioplatecarpine genus, although marginal Plioplatecarpus teeth can usually be distinguished by their more acute distal curvature, delicate form, and finely pointed tips (cf., e.g., Williston, 1898, pl. 13; Dollo, 1913, pl. 25, fig. 2; Kuypers et al., 1998, pl. 6). The overall morphology of the teeth in Plioplatecarpus suggests that they had an even more pronounced piercing function than those of Platecarpus. Moreover, the strongly backward-curved crowns of Plioplatecarpus probably aided in the transport of the prey towards the gullet (see Massare, 1987).

\section{Platecarpus sp. \\ (Figure 2)}

Material. Two isolated marginal tooth-crowns, $\mathrm{n}^{\circ}$. MN 6940-V from Oiteiro 28, upper Turonian, and $\mathrm{n}^{\circ}$. MN 6941-V from Mucuri 7 (2 km S of Oiteiro 28), lower Coniacian, Sergipe Basin, northeastern Brazil.

Description. Specimen MN 6940-V (Figure 2a) is an anteriorly situated marginal tooth-crown with a slightly worn apex and much of its labial face broken off. As preserved, the crown measures $16.2 \mathrm{~mm}$ in height (when measured at a right angle to the plane formed by the base of the enamel) and $6.9 \mathrm{~mm}$ in basal width (original width is estimated at approximately $8.5 \mathrm{~mm}$ ). The lower half of the lingual surface displays indistinct, slightly concave facets separated by weak ridges, whereas the upper half (as well as the preserved apical portion of the labial face) is nearly smooth. The central portion of the lingual face is ornamented by fine, densely spaced hairline striations, beginning a few $\mathrm{mm}$ up the base of the enamel and reaching approximately to the mid-point of the height of the crown. Unserrated anterior and posterior carinae divide the crown into a narrow, almost flat (apical) labial face and a U-shaped lingual surface. In lateral view, the tooth-crown is gently curved medioposteriorly.

The second and larger specimen, MN 6941-V (Figure $2 \mathrm{~b}$ ), is a lateroposterior tooth-crown, measuring $18.1 \mathrm{~mm}$ high and $11.0 \mathrm{~mm}$ wide. It has a worn and somewhat medioposteriorly curved apex. In basal cross-section, the crown is elliptical with a gently convex labial face and inflated lingual surface. Towards the apex, the labial surface widens at the expense of the lingual face, and the two surfaces become almost equally convex. Anterior and posterior carinae are present, both lacking serrations. Low and gently rounded crests divide the labial and lingual surfaces into 
gently concave facets. There are seven discernible facets on the proximal half of the labial face, whereas the lower portion of the lingual surface displays a large number of closely spaced facets. The lower two-thirds of the lingual face exhibits a fine pattern composed of anastomosing and undulating striae.

Remarks. With their delicate lingual striae, gently concave facets, and unserrated carinae, the two tooth-crowns from the Sergipe Basin agree very well in morphology with teeth of Platecarpus from the upper Coniacian-lowermost Campanian Smoky Hill Chalk Member of the Niobrara Formation in western Kansas, USA (e.g., FHSM VP-13810 $[P$. planifrons] and PMU R198 [P. tympaniticus]), and with those in the dentition of $P$. bocagei from the upper(?) Turonian of Angola (Antunes, 1964, pl. 17, fig. 1, pl. 21, fig. 2). It seems, nonetheless, premature at this point either to erect a new species, or to assign the Sergipe specimens to a described species (including the approximately contemporaneous $P$. bocagei) because of the fragmentary state of the material at hand and the lack of high-quality illustrations of teeth of $P$. bocagei, which would perhaps allow this nominal species to be separated from $P$. tympaniticus and $P$. planifrons from a dental point of view. Hence, the Sergipe specimens are kept in open nomenclature, pending the discovery of more complete material. Besides their overall morphological similarity, the two tooth-crowns described herein show a few differences. These distinguishing characters (e.g., in slenderness and curvature) are probably linked to different positions on the dental ramus, although the differences in facet development may attest to intraspecific variation.

\section{DISCUSSION}

During the initial phase of the Late Cretaceous, the global marine reptile fauna underwent a profound reorganization. The highly specialized ichthyosaurs that had inhabited epeiric seas and oceans since the Early Triassic (e.g., Callaway \& Brinkman, 1989) disappeared (Bardet, 1995), and many forms of marine crocodilians were on the wane (Bakker, 1993; Bardet, 1995). Among the groups that benefited from this worldwide faunal turnover were the mosasaurs. Following the demise of the last ichthyosaurs, this family of aquatic reptiles invaded coastal waters and shallow seas some time during the Turonian (or perhaps even earlier), and soon became top predators of the world's oceans.

Despite more than two hundred years of intense research, the origin and early evolution of mosasaurs are still imperfectly known. The closest inferred relative to 'true' mosasaurs sensu Bell (1997) is the early Turonian mosasauroid Tethysaurus nopcasi Bardet et al., 2003, which seemingly fills the gap between the mid-Cretaceous semi-aquatic aigialosaurs and the Late Cretaceous mosasaurs (Bardet et al., 2003). The study of the transition of mosasaurs from these primitive reptiles has contributed significantly to the understanding of large-scale evolutionary patterns (see Carroll, 1997). The relationships between mosasauroids (i.e. mosasaurs, Tethysaurus Bardet et al., 2003 and aigialosaurs) and other reptiles remain controversial. Many workers (e.g., deBraga \& Carroll, 1993) favour the idea that the mosasauroids are derived varanoid lizards (i.e., within the order Sauria), although recent studies (e.g., Lee et al., 1999) have revived an old theory (e.g., Cope, 1869) that the mosasauroids form a sister group to modern snakes (order Ophidia). Russell (1967) suggested that two ancestral lineages of the Mosasauridae; one Clidastes-like and one Platecarpus-like, gave rise to all subsequent mosasaur taxa. In this scenario, a Platecarpus-like ancestor, derived from an advanced aigialosaur stock, would have diversified and eventually evolved into all mosasaur species included in the subfamilies Plioplatecarpinae and Tylosaurinae, whereas mosasaurine mosasaurs would represent derivates of a Clidastes-like ancestor. Recently, Bell \& Polcyn (2004) suggested that the Mosasauridae might be polyphyletic. However, as their conclusions are tentative and data matrix is under development, the traditional phylogeny is adopted here.

The occurrence of the genus Platecarpus in late Turonian times (Angola, Brazil) is in agreement with its inferred basal position within the systematics of the Mosasauridae and further supports Russell's (1967) hypothesis of a Platecarpus-like ancestor for the Plioplatecarpinae and Tylosaurinae. The Brazilian occurrence extends the Turonian record of the genus from West Africa (Angola) to the opposite margin of the then narrow South Atlantic Ocean. Thus, it appears that the origin of Platecarpus is to be found in the northern part of the incipient South Atlantic.

\section{ACKNOWLEDGEMENTS}

We thank Ismar de S. Carvalho (UFRJ, Rio de Janeiro) for information on the mosasaurs from the São Luís Basin, Edilma de J. Andrade (Heidelberg) for unpublished data on inoceramids, and the reviewer Nathalie Bardet (Muséum National d'Histoire Naturelle, Paris) for constructive criticism of the manuscript. P.B. thanks Suzana I. Bengtson (Heidelberg), Diogenes de A. Campos (DNPM, Rio de Janeiro) and Petrobras S.A. (Aracaju and Rio de Janeiro) for field and logistic assistance. The field work was financed by the Swedish Natural Science Research Council (NFR, now Vetenskapsrådet; grants G2320 and G3475).

\section{REFERENCES}

Andrade, E.J.; Seeling, J. \& Bengtson, P. 2003. CenomanianConiacian (Cretaceous) inoceramid biostratigraphy of the Sergipe Basin, Brazil. In: GEOWISSENSCHAFTLICHES LATEINAMERIKA-KOLLOQUIUM, 18, 2003. Zusammen- 
fassungen der Tagungsbeiträge / Abstracts. Terra Nostra: Schriften der Alfred-Wegener-Stiftung, 2003(2): 24.

Andrade, E.J.; Seeling, J.; Bengtson, P. \& Souza-Lima, W. 2004. The bivalve Neithea from the Cretaceous of Brazil. In: E. Jaillard \& P. Bengtson (eds.) Paleontology and stratigraphy of South America. Journal of South American Earth Sciences, 17(1):25-38.

Antunes, M.T. 1964. O Neocretácico e o Cenozóico do litoral de Angola: I. Estratigrafia; II. Repteis. Lisboa, Junta de Investigações do Ultramar, $259 \mathrm{pp}$.

Arambourg, C. 1952. Les vertébrés fossiles des gisements de phosphates (Maroc - Algérie - Tunisie). Service Géologique du Maroc, Notes et Mémoires, 92:1-372.

Bakker, R.T. 1993. Plesiosaur extinction cycles - events that mark the beginning, middle and end of the Cretaceous. In: W.G.E. Caldwell \& E.G. Kauffman (eds.) Evolution of the Western Interior Basin. Geological Association of Canada, Special Paper, 39:641-664.

Bardet, N. 1995. Evolution et extinction des reptiles marins au cours du Mésozoïque. Palceo Vertebrata, 24(3-4):177-283.

Bardet, N. \& Pereda Suberbiola, X. 2001. The basal mosasaurid Halisaurus sternbergii from the Late Cretaceous of Kansas (North America): a review of the Uppsala type specimen. Comptes Rendus de l'Académie des Sciences, Série IIA - Earth and Planetary Science, 332(6):395-402.

Bardet, N.; Bilotte, M.; Christensen, W.K..; Hansotte, M.; Melchior, P. \& Raynaud, C. 1991. Nouveaux restes et révisions de faunes exceptionelles du Crétacé supérieur audois: les Belemnitellidae et Mosasauridae des Corbières. Bulletin de la Société d'études scientifiques de l'Aude, Carcassonne, 91:11-21.

Bardet, N.; Pereda Suberbiola, X. \& Jalil, N.-E. 2003. A new mosasauroid (Squamata) from the Late Cretaceous (Turonian) of Morocco. Comptes Rendus Palevol, 2(8):607-616.

Bardet, N.; Pereda Suberbiola, X.; Iarochene, M.; Bouya, B. \& Amaghzaz, M. 2004. Mosasaurids from the Maastrichtian phosphates of Morocco. In: A.S. Schulp \& J.W.M. Jagt (eds.) FIRST MOSASAUR MEETING, 2004. Abstract Book and Field Guide, Natuurhistorisch Museum Maastricht, p. 13-14.

Bell, G.L. 1997. A phylogenetic revision of North American and Adriatic Mosasauroidea. In: J.M. Callaway \& E.L. Nicholls (eds.) Ancient Marine Reptiles, Academic Press, p. 293-332.

Bell, G.L. \& Polcyn, M.J. 2004. Polyphyly of Mosasauridae: the growing body of evidence. In: A.S. Schulp \& J.W.M. Jagt (eds.) FIRST MOSASAUR MEETING, 2004. Abstract Book and Field Guide, Natuurhistorisch Museum Maastricht, p. 15.

Bell, G.L. \& VonLoh, J.P. 1998. New records of Turonian mosasauroids from the Western United States. Dakoterra, 5:15-28.

Bell, G.L.; Caldwell, M.W.; Holmes, R.; Wiffen, J. \& McKee, J. 1999. Sea monsters of the South Pacific: on the Late Cretaceous mosasaurs of New Zealand. In: ANNUAL MEETING OF THE SOCIETY OF VERTEBRATE PALEONTOLOGY, 59, 1999. Abstracts of papers, Journal of Vertebrate Paleontology, 19(3):32A.

Bengtson, P. 1983. The Cenomanian-Coniacian of the Sergipe Basin, Brazil. Fossils and Strata, 12:1-78.

Bengtson, P. 1996. Cretaceous ammonites of Brazil. In: W. Kuhnt (ed.) JOST WIEDMANN SYMPOSIUM, 1996. Geologisch-
Paläontologisches Institut der Universität Kiel, BerichteReports, 76:207-213.

Bengtson, P. 1999. Research on Cretaceous ammonites of Brazil in the 20th century and the state of the art. In: SIMPÓSIO SOBRE O CRETÁCEO DO BRASIL, 5, 1999. Boletim, Rio Claro, UNESP, p. 591-598.

Berthou, P.-Y. \& Bengtson, P. 1988. Stratigraphic correlation by microfacies of the Cenomanian-Coniacian of the Sergipe Basin, Brazil. Fossils and Strata, 21:1-88.

Bertini, R.J. 2002. Os fósseis da bacia de Sergipe-Alagoas: Os répteis (amniotas reptilianos). Phoenix, 4(42):1-4.

Brito, I.M.; Bertini, R.J. \& Brito, P.M. 1992. Os vertebrados cretácicos brasileiros: levantamento preliminar. In: SIMPÓSIO SOBRE AS BACIAS CRETÁCICAS BRASILEIRAS, 2, 1992. Resumos expandidos, Rio Claro, UNESP, pp. 99-101.

Burrer, N.; Dietzel, S. \& Bengtson, P. 2002. CenomanianConiacian (Cretaceous) gastropods from the Sergipe Basin, Brazil. In: EUROPEAN MEETING ON THE PALAEONTOLOGY AND STRATIGRAPHY OF LATIN AMERICA (EMPSLA), 3, 2002. Extended abstracts, Toulouse, p. 117-119.

Callaway, J.M. \& Brinkman, D.R. 1989. Ichthyosaurs (Reptilia, Ichthyosauria) from the Lower and Middle Triassic Sulphur Mountain Formation, Wapiti Lake area, British Columbia. Canadian Journal of Earth Science, 26(7):1491-1500.

Carroll, R.L. 1997. Mesozoic marine reptiles as models of long-term, large-scale evolutionary phenomena. In: J.M. Callaway \& E.L. Nicholls (eds.) Ancient Marine Reptiles, San Diego, Academic Press, p. 467-489.

Carvalho, L.B. 1996. A ocorrência de lagartos marinhos (Mosasauridae: Lepidosauria) e sua associação faunística no Cretáceo da Bacia Pernambuco-Paraíba, Nordeste do Brasil. Universidade Federal do Rio de Janeiro, Master dissertation, $194 \mathrm{p}$.

Carvalho, L.B. \& Azevedo, S.A.K. 1998. Proposta taxonômica para os répteis marinhos (Lepidosauria, Mosasauridae) do Neocretáceo da Bacia Pernambuco-Paraíba, Nordeste do Brasil. Boletim do Museu Nacional, Nova série, Geologia, 43:1-14

Conybeare, W.D. 1822: Fossil crocodiles and other saurian animals. In: J. Parkinson, Outlines of oryctology. An introduction to the study of fossil organic remains; especially those found in the British strata: intended to aid the student in his enquiries respecting the nature of fossils, and their connection with the formation of the earth vii, London, Printed for the author, p. 284-304.

Cope, E.D. 1869. On the reptilian orders, Pythonomorpha and Streptosauria. Proceedings of the Boston Society of Natural History, 12:250-266.

Cope, E.D. 1871. [Verbal communication on pythonomorphs.] Proceedings of the American Philosophical Society, 11(85): 571-572.

Cope, E.D. 1872. Catalogue of the Pythonomorpha found in the Cretaceous strata of Kansas. Proceedings of the American Philosophical Society, 12(87):264 and 12(88):265-287.

Cope, E.D. 1874. Review of the Vertebrata of the Cretaceous period found west of the Mississippi River. U.S. Geological Survey of the Territories, Bulletin, 1(2):3-48. 
Cope, E.D. 1875. The Vertebrata of the Cretaceous formations of the West. Report of the United States Geological Survey of the Territories. Washington, Government Printing Office, 303 p.

deBraga, M. \& Carroll, R. L. 1993. The origin of mosasaurs as a model of macroevolutionary patterns and processes. Evolutionary Biology, 27:245-322.

Dollo, L. 1882. Note sur l'ostéologie des Mosasauridae. Bulletin $d u$ Musée Royal d'Histoire Naturelle de Belgique, 1:55-74.

Dollo, L. 1913. Globidens fraasi, mosasaurien mylodonte nouveau du Maestrichtien (Crétacé supérieur) du Limbourg, et l'éthologie de la nutrition chez les mosasauriens. Archives de Biologie, 28:609-626.

Eugênio, W.S. 1994. Caracterização geo-paleontológica do Cretáceo da Baía de São Marcos, Maranhão, Brasil. Universidade Federal do Rio de Janeiro, Master dissertation, 75 p.

Everhart, M.J. 2003. Revisions to the biostratigraphy of the Mosasauridae (Squamata) in the Smoky Hill Chalk Member of the Niobrara Chalk (Late Cretaceous) of Kansas. Transactions of the Kansas Academy of Science, 104(1-2):59-78.

Feijó, F.J. 1995. Bacias de Sergipe e Alagoas. Boletim de Geociencias da Petrobrás, 8 [for 1994]:149-161.

Gasparini, Z. \& del Valle, R. 1981. Mosasaurios: primer hallazgo en el continente Antártico. Antártida, 11:16-20.

Gasparini, Z. \& del Valle, R. 1984. Mosasaurios (Reptilia, Sauria) cretácicos, en el continente Antártico. In: CONGRESO GEOLÓGICO ARGENTINO, 9, 1984. Actas, San Carlos de Bariloche, 4:423-431.

Gervais, P. 1853. Observations relatives aux reptiles fossiles de France. Comptes rendus hebdomadaires des Séances de l'Académie des Sciences, 36:374-377, 470-474.

Gilmore, C.W. 1912. A new mosasauroid reptile from the Cretaceous of Alabama. Proceedings of the U. S. National Museum, 41:479-484.

Hessel, M.H.R. 1988. Lower Turonian inoceramids from Sergipe, Brazil: systematics, stratigraphy and palaeoecology. Fossils and Strata, 22:1-49.

Kauffman, E.G. \& Bengtson, P. 1985. Mid-Cretaceous inoceramids from Sergipe, Brazil: a progress report. Cretaceous Research, 6(3):311-315.

Kiernan, C.R. 2002. Stratigraphic distribution and habitat segregation of mosasaurs in the Upper Cretaceous of western and central Alabama, with an historical review of Alabama mosasaur discoveries. Journal of Vertebrate Paleontology, 22(1):91-103.

Koutsoukos, E.A.M. \& Bengtson, P. 1993. Towards an integrated biostratigraphy of the upper Aptian-Maastrichtian of the Sergipe Basin, Brazil. Documents du Laboratoire de Géologie de Lyon, 125:241-262.

Koutsoukos, E.A.M.; Destro, N.; Azambuja Filho, N.C. de \& Spadini, A.R. 1993. Upper Aptian-lower Coniacian carbonate sequences in the Sergipe Basin, northeastern Brazil. In: T. Simo, B. Scott \& J.P. Masse (eds.) Cretaceous carbonate platforms. American Association of Petroleum Geologists, Memoir, 56:127-144.

Koutsoukos, E.A.M.; Mello, M.R. \& Azambuja Filho N.C. de 1991. Micropalaeontological and geochemical evidence of mid-Cretaceous dysoxic-anoxic enviroments in the Sergipe Basin, northeastern Brazil. In: R.V. Tyson \& T.H. Pearson (eds.) Modern and ancient continental shelf anoxia. Geological Society, London, Special Publication, 58:427-447.
Kuypers, M.M.M.; Jagt, J.W.M.; Peeters, H.H.G.; De Graaf, D.T.; Dortangs, R.W.; Deckers, M.J.M.; Eysermans, D.; Janssen, M.J.J. \& Arpot, L. 1998. Laat-kretaceische mosasauriers uit Luik-Limburg: Nieuwe vondsten leiden tot nieuwe inzichten. Publicaties van het Natuurhistorisch Genootschap in Limburg, 41:4-47.

Lee, M. S.Y., Gell, G.L. \& Caldwell, M.W. 1999. The origin of snake feeding. Nature, 400:655-659.

Lindgren, J. 2004. Early Campanian mosasaurs (Reptilia; Mosasauridae) from the Kristianstad Basin, southern Sweden. Litholund theses, 4:1-21.

Lindgren, J. \& Siverson, M. 2002. Tylosaurus ivoensis: a giant mosasaur from the early Campanian of Sweden. Transactions of the Royal Society of Edinburgh: Earth Sciences, 93:73-93.

Lingham-Soliar, T. 1994. The mosasaur 'Angolasaurus' bocagei (Reptilia: Mosasauridae) from the Turonian of Angola re-interpreted as the earliest member of the genus Platecarpus. Paläontologische Zeitschrift, 68(1-2):267-282.

Lundelius, E. \& Warne, S.S.J. 1960. Mosasaur remains from the Upper Cretaceous of Western Australia. Journal of Paleontology, 34(6):1215-1217.

Manso, C.L.C. \& Souza-Lima, W. 2003. O equinóide Douvillaster Lambert, 1917 na Formação Riachuelo, Bacia de Sergipe, Brasil. Revista Brasileira de Paleontologia, 5:29-37.

Marsh, O.C. 1869. Notice of some new mosasauroid reptiles from the Greensand of New Jersey. American Journal of Science and Arts, 48(144):392-397.

Martin, J.E., Bell, G.L., Fernandez, M.S., Reguero, M., Case, J.A. \& Woodburne, M.O. 1999. Mosasaurs from Antarctica and their bearing on global distributions. In: EUROPEAN UNION OF GEOSCIENCES, 10, 1999. Abstracts, 4, Strasbourg, p. 734.

Martin, L.D. \& Stewart, J.D. 1977. The oldest (Turonian) mosasaurs from Kansas. Journal of Paleontology, 51(5):973-975.

Massare, J.A. 1987. Tooth morphology and prey preference of Mesozoic marine reptiles. Journal of Vertebrate Paleontology, 7(2):121-137.

Novas, F.E.; M. Fernández, M.; De Gasparini, Z.B.; Lirio, J.M.; Nuñez, H. J. \& Puerta, P. 2002. Lakumasaurus antarcticus, n. gen. et sp., a new mosasaur (Reptilia, Squamata) from the Upper Cretaceous of Antarctica. Ameghiniana, 39(2):245-249.

Ojeda, H.A.O. 1982. Structural framework, stratigraphy and evolution of Brazilian marginal basins. Bulletin of the American Association of Petroleum Geologists, 66(6):732-749.

Ojeda, H.A.O. \& Fugita, A.M. 1976. Bacia Sergipe/Alagoas: geologia regional e perspectivas petrolíferas. In: CONGRESSO BRASILEIRO DE GEOLOGIA, 28, 1976. Anais, São Paulo, Sociedade Brasileira de Geologia, p. 137-158.

Oppel, M. 1811. Die Ordnungen, Familien und Gattungen der Reptilien als Prodrom einer Naturgeschichte Derselben. München, Joseph Lindauer, 87 pp.

Páramo-Fonseca, M.E. 2000. Yaguarasaurus columbianus (Reptilia, Mosasauridae), a primitive mosasaur from the Turonian (Upper Cretaceous) of Colombia. Historical Biology, 14:121-131.

Price, L.I. 1953. Restos de mosassáurios de Pernambuco, e considerações sôbre a presença dêstes répteis na Bacia Amazônica do Brasil. Departamento Nacional da Produção Mineral, DGM, Notas preliminares e estudos, 58:1-15. 
Price, L.I. 1957. A presença de Globidens no Cretácico Superior do Brasil. Departamento Nacional da Produção Mineral, DGM, Boletim, 169:1-24.

Russell, D.A. 1967. Systematics and morphology of American mosasaurs (Reptilia, Sauria). Peabody Museum of Natural History, Yale University, Bulletin, 23:1-241.

Russell, D. A. 1988. A check list of North American marine Cretaceous vertebrates including fresh water fishes. Occasional Paper of the Tyrrell Museum of Palaeontology, 4:1-57.

Seeling, J. \& Bengtson, P. 1999. Cenomanian oysters from the Sergipe Basin, Brazil. Cretaceous Research, 20(6):747-765.

Seeling, J. \& Bengtson, P. 2003a. The Late Cretaceous bivalve Didymotis Gerhardt, 1897 from Sergipe, Brazil. Paläontologische Zeitschrift, 77(1):153-160.

Seeling, J. \& Bengtson, P., 2003b. The bivalve Pinna cretacea (Schlotheim, 1813) in the Cretaceous of Brazil. Acta Palaeontologica Polonica, 48(3):475-480.

Smith, A.B. \& Bengtson, P. 1991. Cretaceous echinoids from northeastern Brazil. Fossils and Strata, 31:1-88.

Souza-Lima, W. 2001. Macrofaunas campanianas e ambientes deposicionais da Formação Calumbi, bacia de Sergipe-Alagoas, Brasil. Universidade Federal do Rio de Janeiro, Doctoral thesis, $366 \mathrm{p}$.
Souza-Lima, W., Andrade, E.J., Bengtson, P. \& Galm, P.C. 2002. A bacia de Sergipe-Alagoas: evolução geológica, estratigrafia e conteúdo fóssil - The Sergipe-Alagoas Basin: geological evolution, stratigraphy and fossil content. Phoenix, Edição especial, 1:1-34.

Thévenin, A. 1896. Mosasauriens de la Craie grise de VauxÉclusier près de Péronne (Somme). Bulletin de la Société Géologique de France, Série $3^{\text {me }}$, 24:900-916.

Thurmond, J.T. 1969. Notes on mosasaurs from Texas. Texas Journal of Science, 21(1):69-79.

Vilas Bôas, I. \& Carvalho, I.S. 2001. Répteis marinhos (Mosasauria e Plesiosauria) do Cretáceo Superior da Bacia de São Luís (Maranhão, Brasil). In: D.F. Rossetti, A.M. Góes \& W. Truckenbrodt (eds.) O Cretáceo na Bacia de São Luís-Grajaú, Belém, Museu Paraense Emílio Goeldi, p. 223-233.

Williston, S.W. 1897. Range and distribution of the mosasaurs, with remarks on synonymy. Kansas University Quarterly, 4(4):177-185.

Williston, S.W. 1898. Mosasaurs. In: S.W. Williston (ed.) Paleontology, Part 1, Upper Cretaceous. The University Geological Survey of Kansas, 4(5):81-347.

Wiman, C. 1920. Some reptiles from the Niobrara Group in Kansas. Bulletin of the Geological Institutions of the University of Uppsala, New series, 18:9-18.

Received August, 2004; accepted January, 2005. 